\title{
Risk analysis associated with secondary water pollution in selected agglomerations of the Silesian Voivodship
}

\author{
Izabela Zimoch, and Ewelina Bartkiewicz, ${ }^{1, *}$ \\ ${ }^{1}$ Silesian University of Technology, Faculty of Energy and Environmental Engineering \\ Institute of Water and Wastewater Engineering, ul. Konarskiego 18, 44-100 Gliwice, Poland
}

\begin{abstract}
Water quality is the most important parameter related to water intended for human consumption. The main task of water supply companies is to keep water quality at the possible highest level. Water, which consumers receive in their homes, is the final product of a multistage processing, which aims to obtain water with the required physico-chemical and biological composition. Nevertheless, during transport through the Water Supply System (WSS), water reacts with various factors, sometimes causing secondary pollution. An important threat associated with water quality reduction is disinfection by-products (DBP), formed during the oxidation of organic compounds and some inorganic compounds found in water. DBPs has carcinogenic properties, that's why they are threats for human health. The article presents the results of water quality analysis and risk assessments. In research the real WSS, which supplies water to selected Silesian agglomeration, was analyzed. The work uses laboratory tests of selected water parameters. Statistical methods were used to determine the causes of water quality deterioration.
\end{abstract}

\section{Introduction}

Ensuring high water quality intended for consumption is one of the main tasks for waterworks. Low water quality causes a number of threats to human health [1-4]. To ensure the water stability in the distribution system, a disinfection process is used. The aim of disinfection is to destroy living and spore forms of pathogenic organisms. The most commonly used disinfectants are various forms of chlorine, because of its high oxidation potential properties and low costs. Chlorination also limits microbial contamination in the water supply system. However, the organic compounds present in the water and some of the inorganic compounds, react with the free chlorine forming the so-called disinfection by-products (DBPs). Currently, more than a thousand forms of DBPs [5] are known, the most frequent DBPs include THMs and haloacetic acids (HAA). The first of these are regulated by the Regulation of the Minister of Health of 7 December 2017 on the quality of water intended for human consumption, in which the permissible

* Corresponding author: ewelina.bartkiewicz@polsl.pl 
concentration of THMs (sum of trichloromethane, bromodichloromethane, dibromochloromethane and tribromethane) in water is specified. Disinfection by-products have become a serious health threat due to their potential teratogenicity, carcinogenicity and mutagenicity [6-11]. In table No. 1 are listed examples of diseases caused by DBPs exposure to the human body. DBPs also affect the reproductive system and the course of pregnancy [5]. THMs, and other DBPs, can get into the body by water consumption, as well by inhalation and contact with the skin [12-14]. These compounds can be accumulate in the body, and the effects of DBPs impact can be noticeable even after several years.

Two mechanisms are responsible for creating the DBPs in the water distribution system: (1) reduction, oxidation or disproportionation of the disinfectant and (2) oxidation reaction of compounds present in the water by the disinfectant $[15,16]$. Disinfection by-products are formed when their precursors react with the disinfectant. The main precursors to DBP present in water are natural organic substances (NOMs), which are generally associated with the quality of surface waters [17]. Seasonal variation in the formation of DBP is observed, many studies suggest that these compounds are usually higher in the summer because the organic matter content in the water source increases [18]. An important element in the creation of DBPs is the type and dose of disinfectant. Less DBPs are formed using ozone than with chlorine dioxide [19]. An issue worth considering in the creation of DBPs is the spatial variability of these compound in the distribution system. In the literature, only a few works can be found devoted to this task. Problems with determining the spatial variability of DBPs in the water distribution system are related to the structure, flow time and hydraulic conditions [20]. Water supply system operating conditions (including water flow and flow time) are parameters that depend on many factors and are difficult to determine, therefore tests based on hydraulic parameters are subject to a certain error.

The paper presents the spatial and seasonal variability of THM concentration in the distribution system. The carcinogenic risk for THMs exposure via ingestion pathway was determined based on the possessed data.

Table 1. Individual-based studies related to chlorination byproduct exposure [10].

\begin{tabular}{|c|c|c|c|c|}
\hline $\begin{array}{c}\text { Author (ref); } \\
\text { Year }\end{array}$ & $\begin{array}{c}\text { Cancer sites; years of } \\
\text { diagnosis }\end{array}$ & $\begin{array}{c}\text { No. Of } \\
\text { cases }\end{array}$ & Study location & Exposure timing \\
\hline [21] & $\begin{array}{c}\text { Bladder, liver, kidney; } \\
\text { 1963-75 }\end{array}$ & $81,45,31$ & $\begin{array}{l}\text { Western Maryland } \\
\text { (USA) }\end{array}$ & $\begin{array}{c}\text { Years in } 1963 \\
\text { domicile }\end{array}$ \\
\hline [22] & Bladder;1978 & 2805 & 10 locations in USA & Lifetime \\
\hline [23] & Bladder; 1975-92 & 294 & $\begin{array}{l}\text { Western Maryland } \\
\text { (USA) }\end{array}$ & $\begin{array}{c}\text { Years in } 1975 \\
\text { domicile }\end{array}$ \\
\hline [24] & Bladder; 1988-89 & 327 & Colorado (USA) & Age 20 to interview \\
\hline
\end{tabular}




\begin{tabular}{|c|c|c|c|c|}
\hline & & & & \\
\hline$[25]$ & Colon; 1978-80 & 200 & $\begin{array}{c}\text { North Carolina } \\
\text { (USA) }\end{array}$ & $1953-78$ \\
\hline$[26]$ & Colon & 347 & Wisconsin (USA) & Lifetime \\
\hline$[27]$ & Pancreas; 1975-89 & 101 & $\begin{array}{c}\text { Western Maryland } \\
\text { (USA) }\end{array}$ & $\begin{array}{c}\text { Water source in } \\
1975\end{array}$ \\
\hline
\end{tabular}

\section{Research object}

The study subject is the selected subsystem of the biggest collective Water Distribution System (WDS) in Poland, which is located in the southern-west of Poland in Silesian region. Analyzed WDS is composed of Water Treatment Plant A (WTP A), pumping station B (PS B) and storage tanks C (ST C). Figure 1 shows scheme of analyzed WDS.

WTP A is the second largest (in terms of water production) station of the main water supply system. The average daily water production of this station is 50000 cubic meter and it provides water to about 334000 people. WTP A is based on surface water captured from the Soła cascade basin. The water treatment system is based on basic processes such as coagulation, filtration and disinfection. The process of coagulation is guided on the filters with aluminum sulphate (contact coagulation). The filters have been designed as a pressure with a sand layer. Water disinfection is carried out using chlorine gas. Pumping station B is located $32 \mathrm{~km}$ from WTP A. The water that flows into pumping station is subjected to another disinfection, this time with sodium hypochlorite. Pumping station B, depending on water demand, transports water in the amount of 45000 cubic meter per day. Storage tanks $\mathrm{C}$ are located $12 \mathrm{~km}$ from the pumping station $\mathrm{B}$. In storage tanks $\mathrm{C}$ the water disinfection is also carried out with sodium hypochlorite. The $\mathrm{C}$ tanks transport water in three directions. For the purpose of research, tanks $\mathrm{C}$ are the final object. The analyzed main network consists of reinforced concrete pipes with a diameter of $1500 \mathrm{~mm}$ (section between WTP A and PS B) and steel pipes with a diameter of $1400 \mathrm{~mm}$ (section between PS B and ST C). The water flow rate is in the range of $0.3-0.32 \mathrm{~m} / \mathrm{s}$ for the section between WTP and PS and $0.28-0.34 \mathrm{~m} / \mathrm{s}$ for the section between PS and ST. The average water demand for this area is about 17,000 meters per day, thus supplying around 115000 people. 


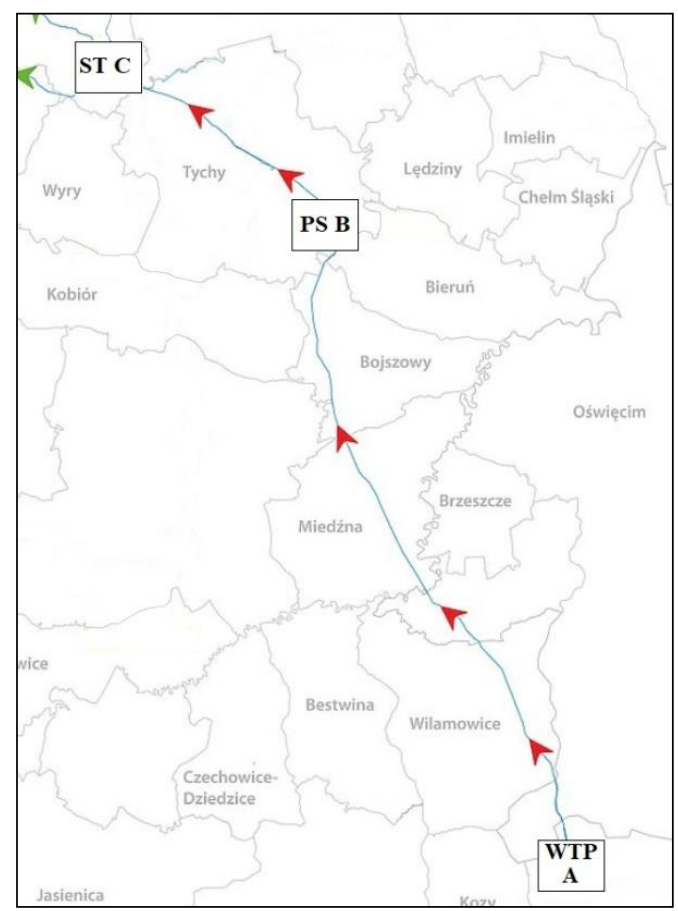

Fig. 1. Scheme of Water Supply System.

\section{Research methodology}

\subsection{Water quality}

Drinking water samples for analysis were collected between January 2016 and December 2018. Samples were collected at WTP A, PS B and ST C, four times a month (average number of samples per month) as part of water quality control. Water tests included physicochemical and biological parameters of water. Figure 2 shows the variability of temperature, $\mathrm{pH}$ and THM from the period of 3 years. At Table 2 we gathered basic statistics of chloroform, bromodichloromethane, dibromochloromethane, bromoform and sum of THMs. 


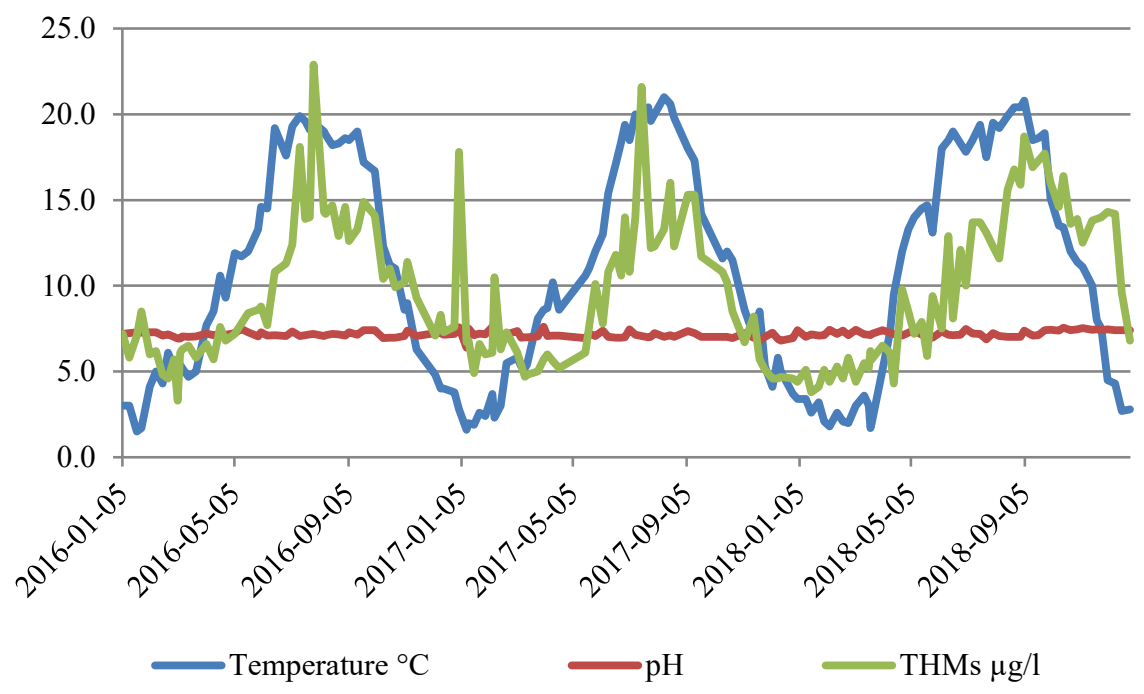

Fig. 2. Variability of selected water parameters in the period 2016-2018 at WTP A.

Table 2. Distributions of THMs concentrations.

\begin{tabular}{|c|c|c|c|c|c|c|}
\hline \multicolumn{2}{|c|}{ Parameters } & CHCl $_{3}$ & CHCl2Br $_{2}$ & CHClBr $_{2}$ & CHBr $_{3}$ & THMs \\
\hline \multirow{4}{*}{ WTP A } & Min & 0.00 & 0.00 & 0.00 & 0.00 & 3.30 \\
\cline { 2 - 7 } & Max & 19.8 & 7.30 & 1.40 & 1.00 & 22.90 \\
\cline { 2 - 7 } & Mean & 8.68 & 1.47 & 0.35 & 0.07 & 9.93 \\
\cline { 2 - 7 } & SD & 4.29 & 1.23 & 0.25 & 0.14 & 4.41 \\
\hline \multirow{4}{*}{ PS B } & Min & 7.50 & 1.40 & 0.00 & 0.00 & 10.10 \\
\cline { 2 - 7 } & Max & 30.70 & 5.70 & 1.90 & 0.30 & 34.70 \\
\cline { 2 - 7 } & Mean & 16.83 & 2.70 & 0.47 & 0.06 & 19.55 \\
\cline { 2 - 7 } & SD & 4.37 & 0.78 & 0.27 & 0.08 & 5.06 \\
\hline \multirow{4}{*}{ ST C } & Min & 3.30 & 1.10 & 0.00 & 0.00 & 4.40 \\
\cline { 2 - 7 } & Max & 33.9 & 5.40 & 1.50 & 0.30 & 38.10 \\
\cline { 2 - 7 } & Mean & 19.15 & 2.99 & 0.51 & 0.06 & 22.16 \\
\cline { 2 - 7 } & SD & 5.82 & 1.00 & 0.23 & 0.08 & 6.67 \\
\hline
\end{tabular}

Figure 3 shows the seasonal variation of THM concentration in water. The highest THM concentrations occurred in summer and autumn. 


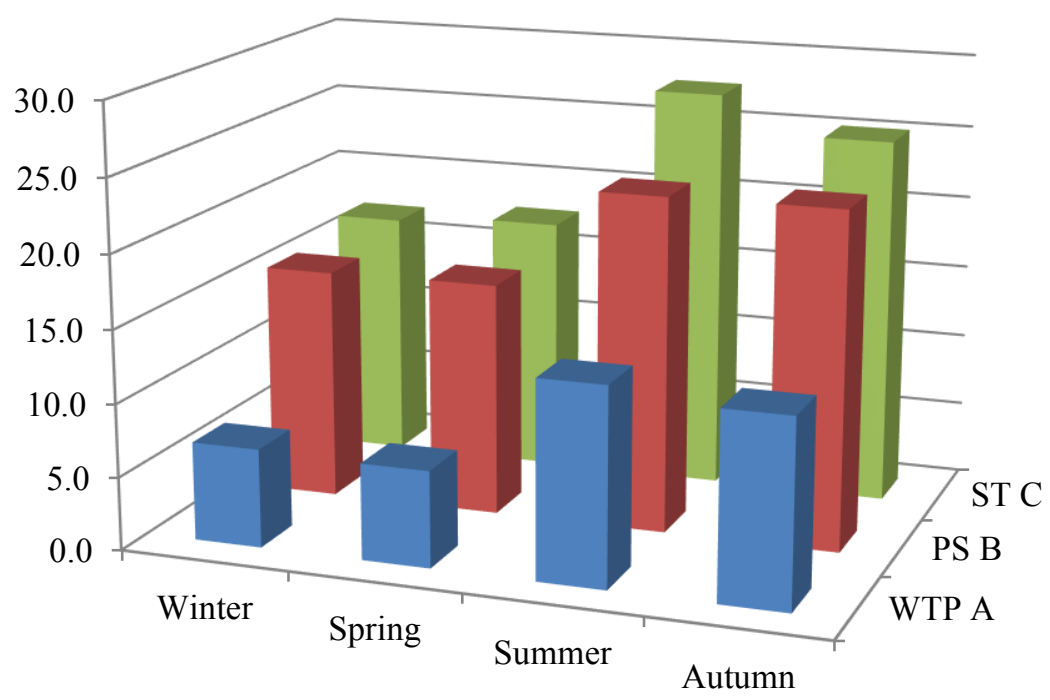

Fig. 3. Average THMs concentrations at points WTP A, PS B and ST C for each season.

\subsection{Risk assessment}

Based on THMs data, a human health risk assessment was conducted to determine the carcinogenic risk associated with exposure to THMs via ingestion pathway.

For calculation of lifetime daily exposure for ingestion pathway the following equation was used [28]:

$$
C D I_{\text {ing }}=\frac{C_{w} \cdot I R \cdot E F \cdot C F}{B W \cdot A T}
$$

where: $C D I_{\text {ing }}$ is chronic daily intake, $\mathrm{mg} / \mathrm{kg} / \mathrm{d}, C_{W}$ is the chemicals concentration in water, $\mu \mathrm{g} / \mathrm{L}, I R$ the ingestion rate, L/day, $E F$ the exposure frequency, days/year or events/year, $E D$ the exposure duration, year, $\mathrm{CF}$ is the mass conversion factor from $\mu \mathrm{g}$ to $\mathrm{mg}, B W$ the body weight, $\mathrm{kg}$, and $A T$ the average time, days. The risk assessment associated with THMs exposure via ingestion pathway was calculated using following equation [29]:

$$
\text { Risk }=\mathrm{CD} \mathrm{I}_{\text {ing }} \cdot \mathrm{CSF}_{\text {oral }}
$$

where: $C S F_{\text {oral }}$ is cancer slope factor, $\mathrm{mg} / \mathrm{kg} / \mathrm{d}$. The minimum, maximum and mean THMs concentrationsat PS B and ST C points were used for the calculations, which will represent THMs concentrations respectively at section WTP A - PS B and PS B - ST C. At Table 3 we gathered all exposure parameters and population characteristics. Ingestion rate was chosen as the minimum recommended amount of water that a person should consume. Exposure duration and body weight was recommended by USEPA [28] as 70 years 
exposure and average weight for male $70 \mathrm{~kg}$ and for female $60 \mathrm{~kg}$. Exposure frequency is the number of days, where THMs has appeared. CSF oral values were taken from [30].

Table 3. Exposure parameters and population characteristics.

\begin{tabular}{|c|c|c|c|c|}
\hline Parameters & Symbol & Unit & Distribution & Value \\
\hline \multirow{2}{*}{$\begin{array}{c}\mathrm{CHCl}_{3}, \mathrm{CHCl}_{2} \mathrm{Br}, \mathrm{CHClBr}_{2} \text { and } \\
\mathrm{CHBr} 3 \text { concentration }\end{array}$} & \multirow{2}{*}{$\mathrm{C}_{\mathrm{w}}$} & \multirow{2}{*}{$\mu \mathrm{m} / \mathrm{L}$} & Mean: PS B & Table 1 \\
\hline & & & Mean: ST C & Table 1 \\
\hline Ingestion rate & IR & $\mathrm{L} /$ day & Min & 2.0 \\
\hline Exposure frequency & $\mathrm{EF}$ & day/year & $\operatorname{Max}$ & 365 \\
\hline Exposure duration & ED & year & Mean & 70 \\
\hline Mass conversion factor & $\mathrm{CF}$ & - & & 0.001 \\
\hline \multirow{2}{*}{ Body weight } & \multirow{2}{*}{$\mathrm{BD}$} & \multirow{2}{*}{$\mathrm{kg}$} & Mean: Male & 70 \\
\hline & & & Mean: Female & 60 \\
\hline Average time & $\mathrm{AT}$ & days & Mean & $70 \times 365$ \\
\hline Cancer slope factor forCHCl 3 & $\mathrm{CSF}_{\text {oral }}$ & $\mathrm{mg} / \mathrm{kg} \cdot \mathrm{d}$ & & 0.0310 \\
\hline Cancer slope factor for $\mathrm{CHCl}_{2} \mathrm{Br}$ & $\mathrm{CSF}_{\text {oral }}$ & $\mathrm{mg} / \mathrm{kg} \cdot \mathrm{d}$ & & 0.0620 \\
\hline Cancer slope factor for $\mathrm{CHClBr}_{2}$ & $\mathrm{CSF}_{\text {oral }}$ & $\mathrm{mg} / \mathrm{kg} \cdot \mathrm{d}$ & & 0.0840 \\
\hline Cancer slope factor for $\mathrm{CHBr}_{3}$ & $\mathrm{CSF}_{\text {oral }}$ & $\mathrm{mg} / \mathrm{kg} \cdot \mathrm{d}$ & & 0.0079 \\
\hline
\end{tabular}

\section{Result and discussion}

The maximum THM concentration was in ST C and is equal 38.10.The standard deviation value indicates a high variability of the THM content in water. During the study period, there were no exceeded THM concentrations specified in the Regulation of the Minister of Health of 7 December 2017. The highest THM concentrations occurred in summer and autumn caused by the variability of water quality in these periods (algae blooms, leaf fall). Chloroform was the major contributor to the total concentration of THMs. The highest concentration of chloroform varied between 3.30 and $33.90 \mu \mathrm{g} / \mathrm{L}$ and occurs in ST C. Chloroform is the most common factor affecting THMs concentration in water. Based on the research, it was found that chloroform occurs in every sample, as well as bromodichloromethane. Whereas, dibromochloromethane and bromoformare present in about $90 \%$ of samples.

The chronic daily intake of THMs via ingestion pathway is shown in Table 4 and in Table nr 5 is shown results for cancer risk. The highest lifetime risk of $2.74 \cdot 10^{-5}$ was obtain for female in section PS B - ST C. The lowest lifetime cancer risk was obtained for bromoform, values in order of $10^{-8}$. The average lifetime cancer risk for total THMs in both section was $2.41 \cdot 10^{-5}$, which is higher than EPA recommended cancer risk value about 24 times. The percentage contribution of average cancer risks: $71.5 \%$ for $\mathrm{CHCl}_{3}, 22.9 \%$ for $\mathrm{CHCl}_{2} \mathrm{Br}, 5.50 \%$ for $\mathrm{CHClBr}_{2}$ and $0.10 \%$ for $\mathrm{CHBr}_{3}$.

Table 4. Chronic daily intake of THMs via ingestion pathway.

\begin{tabular}{|c|c|c|c|c|c|c|}
\hline Section & Gender & $\mathbf{C H C l}_{\mathbf{3}}$ & $\mathbf{C H C l}_{2} \mathbf{B r}$ & $\mathbf{C H C l B r}_{2}$ & $\mathbf{C H B r}_{3}$ & Sum \\
\hline \multirow{2}{*}{ WTP A - PS B } & Male & $48.09 \cdot 10^{-5}$ & $7.71 \cdot 10^{-5}$ & $1.35 \cdot 10^{-5}$ & $0.17 \cdot 10^{-5}$ & $57.33 \cdot 10^{-5}$ \\
\cline { 2 - 7 } & Female & $56.11 \cdot 10^{-5}$ & $9.00 \cdot 10^{-5}$ & $1.58 \cdot 10^{-5}$ & $0.20 \cdot 10^{-5}$ & $66.88 \cdot 10^{-5}$ \\
\hline \multirow{2}{*}{ PS B - ST C } & Male & $54.72 \cdot 10^{-5}$ & $8.56 \cdot 10^{-5}$ & $1.46 \cdot 10^{-5}$ & $0.17 \cdot 10^{-5}$ & $64.91 \cdot 10^{-5}$ \\
\cline { 2 - 7 } & Female & $63.83 \cdot 10^{-5}$ & $9.98 \cdot 10^{-5}$ & $1.71 \cdot 10^{-5}$ & $0.20 \cdot 10^{-5}$ & $75.73 \cdot 10^{-5}$ \\
\hline
\end{tabular}


Table 5. Cancer risk associated with THMs exposure via ingestion pathway.

\begin{tabular}{|c|c|c|c|c|c|c|}
\hline Section & Gender & CHCl $_{\mathbf{3}}$ & $\mathbf{C H C l}_{2} \mathbf{B r}$ & $\mathbf{C H C I B r}_{2}$ & $\mathbf{C H B r}_{3}$ & Sum \\
\hline \multirow{2}{*}{ WTP A - PS B } & Male & $1.49 \cdot 10^{-5}$ & $0.48 \cdot 10^{-5}$ & $0.11 \cdot 10^{-5}$ & $1.34 \cdot 10^{-8}$ & $2.08 \cdot 10^{-5}$ \\
\cline { 2 - 7 } & Female & $1.74 \cdot 10^{-5}$ & $0.56 \cdot 10^{-5}$ & $0.13 \cdot 10^{-5}$ & $1.56 \cdot 10^{-8}$ & $2.43 \cdot 10^{-5}$ \\
\hline \multirow{2}{*}{ PS B - ST C } & Male & $1.70 \cdot 10^{-5}$ & $0.53 \cdot 10^{-5}$ & $0.12 \cdot 10^{-5}$ & $1.36 \cdot 10^{-8}$ & $2.35 \cdot 10^{-5}$ \\
\cline { 2 - 7 } & Female & $1.98 \cdot 10^{-5}$ & $0.62 \cdot 10^{-5}$ & $0.14 \cdot 10^{-5}$ & $1.59 \cdot 10^{-8}$ & $2.74 \cdot 10^{-5}$ \\
\hline
\end{tabular}

\section{Conclusions}

The work involved analysis of water quality in terms of the occurrence of disinfection by-products. The spatial and seasonal distribution of pollutants was taken into account. The analysis shows that the highest THMs concentrations occurred in summer and autumn. It was also found that the greater the distance from the WTP, the higher the THMs concentrations. It was also found that the most common factor affecting the occurrence of THM is chloroform. At research the lifetime cancer risk via ingestion pathway was evaluated. The result show that women are more vulnerable than men. The highest cancer risk was obtained for section, which is the farthest from the WTP. The highest degree of risk is associated with chloroform, which is $1.73 \cdot 10^{-5}$ (mean value).

The quality of the analyzed water is good, during the period of research there were no exceedances of the THM concentration recorded in the Regulation of the Minister of Health. The average risk associated with exposure to THMs was $2.41 \cdot 10^{-5}$, which is a low result, however, it exceeds the value recommended by the EPA.

This work was supported by Ministry of Science and Higher Education Republic of Poland within statutory funds as well as BKM-508/RIE-4/2018 research.

\section{References}

1. D. Baruaand, W. B. Greenough, Cholera (Springer Science Business Media, LLC, New York, 1992)

2. S. Ishii, M. J. Sadowsky, Microbes Environ. 23 (2008)

3. S. Khan, M. Shahnaz, N. Jehan, S. Rehman, M. T. Shah, I. Din, J. Cleaner Prod. 60 (2013)

4. I. Zimoch, E. Lobos, Environ. Prot. Eng. 38 (2012)

5. Y. Wang, G. Zhu, B. Engel, Ecotoxicol. Environ. Saf. 170 (2018)

6. J. J. Rook, Water Treat. Exam. 23 (1974)

7. S. E. Hrudey, L. C. Backer, A. R. Humpage, S. W. Krasner, D. S. Michaud, L. E. Moore, J. Toxicol. Environ. Health B Crit. Rev. 18 (2015)

8. S. E. Hrudey, J. Fawell, Water Sci. Technol.-Water Supply 15 (2015)

9. M. Kumari, Ecotoxicol. Environ. Saf. 113 (2015)

10. K. P. Cantor, Cancer Causes and Control (1997)

11. I. Zimoch, E. Lobos, Desalin. Water Treat. 57 (2016)

12. D. A. Savitz, P. C. Singer, A. H. Herring, Am. J. Epidemiol. 164 (2006)

13. Y. M. Tan, K. H. Lao, H. J. Clewell, J. Expo Sci. Environ. Epidemiol. 17 (2007)

14. S. Chowdhury, Sci. Total Environ. 463-464 (2013) 
15. K. N. Shammas, K. L. Wang, Water Engineering - Hydraulics, Distribution and Treatment ( $1^{\text {st }}$ Ed., John Wiley \& Sons, 2016)

16. I. Zimoch, Ochr. Środ. 33 (2011)

17. H. Y. Zhai, X. R. Zhang, Environ. Sci. Technol. 45 (2011)

18. M. J. Rodriguez, J. B. Serodes, P. Levallois, Water Res. 38 (2004)

19. G. Hua, D. A. Reckhow, Water Res. 41 (2007)

20. C. M. Shanks, Jean-B. Sérodes, M. J. Rodriguez, Water Res. 47 (2013)

21. Wilkins Jr, Am. J. Epidemiol. 114 (1981)

22. K. P Cantor, R. Hoover, P. Hartge, JNCI, 79 (1987)

23. D. M Freedman, K. P. Cantor, N. L. Lee, Cancer Causes Control, 8 (1997)

24. M. A. McGeehin, J. S. Reif, J. Becher, E. J Mangione, Am. J. Epidemiol. 138 (1993)

25. R. L Jolley, R. J. Bull, W. P. Davis, S. Katz, M. H. Jr Roberts, V. A. Jacobs, Water Chlorination: Chemistry, Environmental Impact and Health Effects (Vol. 5, Lewis Publishers, Inc., Chelsea, MI (USA), 1985)

26. T. B. Young, D. A. Wolf, M. S. Kanarek, Int. J. Epidemiol. 16 (1987)

27. C. B. IJsselmuiden, C. Gaydos, B. Feighner, Am. J. Epidemiol. 136 (1992)

28. USEPA. Guidelines for exposure assessment. Risk assessment Forum, US Environmental Protection Agency; 1992. Washington DC, EPA/600/Z-92/001

29. H. Amjad, I. Hashmi, M. S. Ur Rehman, M. Ali Awan, S. Ghaffar, Z. Khan, Ecotoxicol. Environ. Saf. 91 (2013)

30. Integrated Risk Information System (IRIS) (2009). USEPA (Electronic data base). Web link: http://www.epa.gov/iris/ (2009) 